\title{
Analysing the Relationship between Price and Online Reputation by Lodging Category
}

\author{
Manuel Rodríguez-Díaz ${ }^{1}{ }^{\circledR}$, Rosa Rodríguez-Díaz ${ }^{2}$, Ana Cristina Rodríguez-Voltes ${ }^{3}$ \\ and Crina Isabel Rodríguez-Voltes ${ }^{3, *}$ (D) \\ 1 Department of Economics and Business, University of Las Palmas de Gran Canaria, \\ 35001 Las Palmas, Spain; manuel.rodriguezdiaz@ulpgc.es \\ 2 Department of Finances and Acounting, University of Las Palmas de Gran Canaria, \\ 35001 Las Palmas, Spain; rosa.rodriguezdiaz@ulpgc.es \\ 3 Instituto Canario de Sicología y Educación, 35007 Las Palmas, Spain; cristinarvoltes@hotmail.com \\ * Correspondence: manuel.rodriguezdiaz@ulpgc.es
}

Received: 5 November 2018; Accepted: 24 November 2018; Published: 28 November 2018

\begin{abstract}
Price is fundamental in the competitive strategy of lodgings. Determining whether a company is setting its prices appropriately in relation to its main competitors and customer expectations is essential in the new digital age. Online reputation is a way of measuring customer ratings and, when shared on the Internet, it generates expectations for future users. On the other hand, websites specializing in tourism constantly provide updated information about the prices offered by lodgings. The purpose of this study is to establish whether there is a relationship between price and the main variables of online reputation (perceived value, added value and perceived quality of service) as well as the function that best suits considering the category of accommodation, using the information available on the website Booking.com. The methodology applied is regression analysis using different functions (linear, logarithmic, inverse, quadratic and cubic). In addition, 4- and 5-star lodgings are analysed separately from those with 3 stars or less, concluding that there are significant differences between the variables that best explain the price, as well as the functions that best achieve this fit. In 4 and 5-star accommodations, the average quality of service variable is the one most related to prices, whereas in 3-star accommodations or less, the added value is the variable most related to prices. The cubic, quadratic and logarithmic functions get the best adjustments. The results obtained are of great interest to the management of the accommodation as customer ratings are linked to price levels in a competitive environment. This methodology facilitates the definition of the strategy and tactics of prices on the basis of real and updated market data, indicating in the conclusions the direct implication in the future development of learning machines and artificial intelligence applied to tourism.
\end{abstract}

Keywords: online reputation; price; online customer review; lodging category; service quality; added value

\section{Introduction}

Prices in the tourism sector are critical for defining the competitive strategy and obtaining the results proposed by companies [1,2]. The competitiveness of tourism companies is developing through the Internet, where the online reputation influences demand and, therefore, price levels [3-5]. The opinions shared by clients on specialized websites are considered by potential users, who can also analyse the lodging price offer [6-10]. Tourist lodging managers, therefore, have to constantly monitor the evolution of their prices in relation to the competition and determine whether they match customer expectations in relation to perceived value and quality of service [11,12]. 
The online reputation is a competitive positioning problem in that customers create expectations based on the information received through the Internet and the price level they want to pay for the service offered by lodgings [8,13]. Customers' online reviews can be transmitted by means of quantitative variables or qualitative opinions [14]. The former considers certain variables in studying lodgings' competitive positioning [15-18]. Another very important type of data obtained on web pages is the category of the accommodation, which is associated with the price level $[19,20]$ and the quality of service that customers perceive $[21,22]$. However, different authors $[13,23,24]$ note that the increase in the category of hotels does not always match the perceived service quality ranking. This inconsistency can influence the competitiveness of tourism firms.

Quantitative variables used to measure online reputation generally assess the constructs of perceived service quality, perceived value and added value [6,8,25-28]. Moreover, qualitative opinions studied through content analysis are used to measure customer satisfaction [14]. Because price is a quantitative variable directly related to the lodging's reputation [1,29-32], it is more appropriate to use the quantitative online reputation variables to determine the possible relationship with price [11].

Although price is an important variable for tourism companies, not many studies have focused on the relationship between price and online reputation. In this context, for Masiero and Nicola [18], it is critical to determine the patterns followed in customers' purchasing behaviour, especially with regard to price sensitivity. In this way, companies will be able to more clearly establish the target segments they address and their main competitors [22]. Therefore, the relationship between prices and online reputation makes it possible to establish a competitive positioning $[16,17]$ and assess whether the price charged matches the service and value created for customers [33-35]. The dynamics of the digital era in tourism signify that the price variable and companies' competitive strategies are being revised jointly and constantly [36] because the price level determines the standard of service quality and value generated for customers [37,38], as well as their satisfaction $[2,33] \mathrm{K}$. In this regard, the lodging category represents a first segmentation of the market, as prices vary according to the category $[19,20]$.

The aim of this research is to study the relationship between price and online reputation, taking into account the lodging category. To the extent that this relationship is established, it will be possible to establish more objectively the strategy and tactics of accommodation prices, in a highly changing and competitive environment. To this end, two groups of companies have been created, those with 4 and 5 stars and those with 3 stars or less. Thus, the variables perceived service quality, added value and perceived value are examined with respect to prices through bivariate regressions with different types of functions. The objective is to establish which variable has the strongest relationship with prices and which of the analysed functions obtains the best fit for each of the two lodging categories. In order to achieve this research objective, the study begins with a review of the literature which presents the different studies carried out on online prices and reputation in tourism. Subsequently, the applied methodology is developed, which is based on regression analysis with different types of functions (linear, logarithmic, inverse, quadratic and cubic), with the aim of establishing the relationship between prices and the variables of perceived service quality, perceived value and added value. The results obtained are presented in the following section, differentiating between 4 and 5-star accommodation and those with 3 stars or less. Finally, the results are discussed and the main conclusions and future lines of research are presented.

\section{Literature Review}

Competitiveness among tourism companies focuses on the type of segment they are targeting and the category provides a means to perform a first segmentation of the market [18-20]. The price level is initially determined by the lodging category, which should coincide with the level of quality offered to customers [39]. From this point of departure, tourism firms have to compete in a highly technology-influenced marketplace, where Internet communications create a dynamic of constant price analysis [8]. 
The scope of revenue management has been evolving, gaining considerable importance in the strategy of tourist lodgings [39]. In this area, pricing is the key to obtaining the highest possible level of revenue in a competitive environment $[40,41]$. The pricing strategy is determined on the basis of the market segments the lodgings target, as well as on the partial occupancy objectives by time periods [22]. The process consists of previously planning how the lodging will be progressively occupied, as well as the prices established by the market segment. Any change in its competitors' demand or strategy will cause the lodging to rethink its pricing policy [31].

On the other hand, the online reputation, based on comments and evaluations shared by customers on the Internet, is now strongly emerging. Thus, the demand is affected by competitive factors based on perceived value, perceived service quality and customer satisfaction with the contracted service [24,41-48]. Therefore, tourism companies have to implement approaches based on clients and their preferences about the different alternatives they have when making decisions [22].

Different authors have studied the impact of online reputation on the price customers are willing to pay. Yacouel and Fleischer [8] demonstrated that lodgings with a good track record in the quality of service offered get their customers to pay higher prices. Kim and Park [2] demonstrated the predictive power of the level of customer satisfaction in lodging results. Ye et al. [31] demonstrated that the online customer feedback is related with the demand for accommodations. Moreover, Xie et al. [46] studied the relationship between specific attributes of quality of service and lodging performance.

Tourism prices have been analysed in relation to different perspectives, such as pricing strategy and discounts [22,49-52], category [19,20], advertising [53,54], customer perceptions [55,56], key factors [17,57-59], performance [31,40,46,60-63], competitive positioning [11,13] and clients' selection of lodgings [33].

Although several research studies have been carried out to determine the relationship between prices and online reputation $[1,2,8,11,30,31,46,64]$, the relationship between the main constructs evaluated in online reputation, prices and the lodging category has not been analysed. This analysis is critical in determining, from a practical perspective, the level of competitiveness of an accommodation and the appropriateness of the pricing strategy applied by companies.

An essential factor in studying tourism prices is that they are subject to great seasonality [54]. In general, destinations differentiate between high and low seasons, although changes in prices can also occur within each season [11]. Likewise, the level of competitiveness and occupancy reached at any given time may lead to rethinking the pricing strategy [17]. Therefore, price settings a dynamic process where prices are adjusted upwards or downwards according to objectives and changing market trends [57]. Any changes in the environment can produce an alteration in the occupancy level and income. This means that lodging managers must constantly make decisions that require technological tools with up-to-date information and decisions [22].

Online reputation is based on information transmitted by customers over the Internet through comments, evaluations, or images [10]. It is an interactive process in which information is exchanged between clients and companies, creating a mental image of the service being offered $[65,66]$. This process determines the creation of client expectations that must be satisfied so that they do not perceive deficiencies in the quality of the service received. Because information is freely transmitted over the Internet, companies lose much of their control over communication. Therefore, they have to develop dynamic tools to implement corrective measures where price is crucial [67-71].

Quantitative evaluations on tourism websites generally use scale of variables to measure the value perceived and the quality of service perceived [6,14,46,72]. However, according to Rodriguez-Díaz et al. [13], added value is calculated from customer evaluations of the perceived value and quality of service perceived. On the one hand, perceived value is a construct directly related to the quality of service received by customers and vice versa, for the price they have to pay and it is a subjective concept that is depending on customers' characteristics and perceptions $[37,44,73-80]$. Perceived value is habitually measured over the Internet through a single item because users do not usually respond to extensive surveys [81]. Otherwise, quality of service perceived is measured through 
a scale of variables that tap the main attributes customers assess related to their expectations and perceptions of the service they receive [42,44-48].

The category is a decisive factor in the market positioning and competitiveness of tourism firms. In this context, different studies have demonstrated that the highest category lodgings tend to be evaluated more rigorously by customers, which produces an imbalance between online reputation, category and lodging prices $[23,24]$. This situation was also verified empirically by Rodríguez-Díaz et al. [13], who demonstrated through the concept of added value applied to tourism [82] that higher category lodgings tend to obtain negative added value because customers who pay higher prices are more demanding. Therefore, it is necessary to carry out studies on the relationship between prices and online reputation according to the category of lodgings because it conditions the segmentation of the market and the degree of customers' expectations based on the price they pay.

\section{Research Methodology}

To implement the empirical research, information was obtained from 403 lodgings on the Booking.com website. These companies are located in three competing tourist destinations mainly oriented on sun and beach market segment: Sur de Gran Canaria and Tenerife located in Canary Islands (Spain) and Agadir located in Morocco. The destination of Canary Islands is one of the most important in Europe, receiving more than 12 million tourists annually [83]. Agadir is located in the Souss Massa Drâa region and receives annually around four million tourists [84].

The customer reviews of the lodgings analysed was 69,024. Of these, 38,096 evaluations were carried out in Gran Canaria, whereas 20,950 were analysed in Tenerife, and, finally 9978 in the destination of Agadir. The number of lodgings studied was: 272 in Gran Canaria, 82 in Tenerife and 49 in Agadir. The sample was obtained by accessing the Booking website and selecting each of the destinations by date according to the type of season. Subsequently, the information of the accommodations was obtained following the order that appeared in the web page. Those lodgings that had few comments were not taken into account (less than 50), in order to avoid bias. When a certain accommodation was not available on the dates that were introduced and, therefore, the price was not on the web, the date was modified in a limited form, in order to find its price in the period analysed. The accommodations that were not available on the web in many periods of time were not considered. In this way, it is guaranteed that the bias of the information is the least possible as to the selection of the accommodations and the selected period of time.

Booking.com uses a 10-point scale to measure quantitative customer ratings, where 1 is a very low rating and 10 is a very high rating of the attribute or concept measured. However, these results that appear on Booking.com are obtained by transforming the initial 4-point scale so that 2.5 is the minimum score for each variable, according to Mellinas et al. [85]. Despite this possible bias, Rodríguez-Díaz and Espino-Rodríguez $[27,28]$ show that the measured realized by Booking.com is one of the most reliable and valid in specialized websites on the Internet. Considering these aspects, it can be stated that the Booking scale has a minimum value of 2.5 and a maximum value of 10 .

The quantitative scale applied by Booking.com has seven variables; six measure quality of service and one measures the perceived value. The Wi-Fi variable has not been included in the analysis for several reasons. Firstly, because it is largely conditioned by public infrastructure or external private companies. For example, optical fibre is not available in all destinations or areas of destinations, which makes it difficult to offer this type of service adequately. Secondly, this variable is only measured on the scale used by Booking.com, while other specialised websites such as TripAdvisor or HolidayCheck do not include it. From this it can be deduced that it is not one of the main variables used to measure online reputation. Finally, it is possible that the technological development of the next few years will not require an additional effort on the part of the accommodations to offer this service, since operators will be able to provide it directly. Therefore, the average of the quality of service is evaluated with the variables of personal, cleanliness, service/facilities, comfort and location. The average of the perceived quality of service, which we will call $Q$, is obtained from a mean of 
these variables, whereas the perceived value is evaluated with the variable value for money. As far as the lodging category is concerned, this information and the prices are available on the Booking.com website. Espinet et al. [57], Hung et al. [17] and Jena and Jog [54] point out that prices change throughout the year depending on the season, market segments and level of demand. However, in most cases, price can be differentiated between high and low season [11] and establish the most common maximum and minimum prices in each season. The high season in the studied destinations is winter, where maximum prices are paid in November, February and part of March, whereas the prices are reduced in the first 20 days of December, January and April. Summer is considered the low season because all the Mediterranean destinations are open and, consequently, the number of customers decreases. In summer, the maximum prices are usually found in the last days of July, August and October, whereas the minimum prices are usually offered in May, June and the first days of July.

The purpose of this research is to establish if there are a significant relationship between lodgings' prices and their categories, based on the variables evaluated to measure online reputation. These variables are perceived value $(\mathrm{V})$, average perceived service quality $(\mathrm{Q})$ and added value $(\mathrm{AV})$. To this end, the SPSS statistical package was used to perform bivariate regressions, where the dependent variables were the constructs of online reputation and the independent variables were the four price types analysed. In addition, the sample of lodgings was split into two clusters: (1) those lodgings with a category of 4 and 5 stars; and (2) those with 3 stars or less. The objective is to determine which type of function has the best fit and so regressions of linear, logarithmic, inverse, quadratic and cubic functions were performed, as described below:

- Linear: The equation is $\mathrm{y}=\mathrm{a}+\mathrm{b} 1 * \mathrm{x}$.

- Logarithmic: The equation is $\mathrm{y}=\mathrm{a}+\mathrm{b} * \ln (\mathrm{x})$.

- Inverse: The equation is $y=a+(b / x)$.

- Quadratic: The equation is $\mathrm{y}=\mathrm{a}+\mathrm{b} * \mathrm{x}+\mathrm{c} * \mathrm{x}^{2}$.

- Cubic: The equation is $\mathrm{y}=\mathrm{a}+\mathrm{b} * \mathrm{x}+\mathrm{c} * \mathrm{x}^{2}+\mathrm{d} * \mathrm{x}^{3}$.

\section{Analysis of Results}

The lodgings analysed were divided into two clusters in function of their category. The aim is to establish which function best explains the relationship between online reputation variables and price. The objective is to determine which of the three constructs of online reputation (average quality of service perceived, added value and perceived value) is more related to prices and, at the same time, analyse whether there are differences between the results obtained in each of the groups of categories studied. The results obtained are presented according to the groups of categories analysed, showing the graphs with the different functions considered for the online reputation variables most related to price.

\subsection{Lodgings with 4 and 5 Stars}

The results achieved in the statistical analysis of 4- and 5-star lodgings are shown in Tables 1-3. As far as the perceived value is concerned, Table 1 reveals that the regressions obtained a very low $\mathrm{R}^{2}$ adjusted and so it can be concluded that, based on the data examined, there is no relationship between the perceived value and the different prices studied for these lodging categories. The best results were obtained with the cubic function for minimum and maximum prices in high season, with an $\mathrm{R}^{2}$ adjusted of 0.1926 and 0.1841 , respectively.

The average perceived service quality obtained the best results of the three variables, with a high $\mathrm{R}^{2}$ adjusted for the type of study being carried out (see Table 2). In the regressions of minimum prices in low season, the best results were obtained by the cubic (0.2926), logarithmic (0.2919) and inverse (0.2912) functions. For maximum low season prices, the logarithmic $(0.2962)$, cubic $(0.2883)$ and quadratic $(0.2840)$ functions obtained the highest $\mathrm{R}^{2}$ adjusted. The cubic and quadratic functions resulted in significantly higher $\mathrm{R}^{2}$ adjusted for the minimum prices in high season of 0.5366 and 0.5341 , 
respectively, which shows that the average perceived quality of service is an important variable in determining the price the lodgings in these categories should offer. High results are also obtained for cubic (0.4792), quadratic (0.4791) and logarithmic (0.4622) functions for maximum prices in high season. These results show that there is a close relationship between the online reputation and the prices set by tourist accommodations, based on customers' assessments of the quality of service received in higher category lodgings.

The added value also obtained an acceptable high level of results but without reaching those achieved by the average quality of service perceived (see Table 3). The cubic and logarithmic functions obtained $\mathrm{R}^{2}$ adjusted of 0.2609 and 0.2234 , respectively, for the low season minimum prices, which demonstrate a significant relationship with added value. At maximum prices in low season, the $R^{2}$ adjusted increased to 0.2840 in the cubic function, 0.2763 in the quadratic function and 0.2626 in the logarithmic function. The minimum prices in high season improve the fits obtained, with the cubic function obtaining an $R^{2}$ adjusted of 0.3246 and the quadratic function obtaining an $\mathrm{R}^{2}$ adjusted of 0.3177. Finally, maximum prices in high season also obtained satisfactory results because the cubic function achieves an $R^{2}$ adjusted of 0.3048 and the quadratic function achieves an $R^{2}$ adjusted of 0.3029 . These results show that added value is another online reputation measure to be taken into account in studies on the price of tourist lodgings, even though it obtains results below the average quality of service perceived. Figure 1 shows the graphs of the functions analysed in the online reputation variables that obtained the best results in each type of price.

Table 1. Regression analysis in 4 and 5 stars, with value as dependent variable.

\begin{tabular}{|c|c|c|c|c|c|c|c|}
\hline \multicolumn{8}{|c|}{ Season: Low } \\
\hline \multicolumn{8}{|c|}{ Independent variable: Minimum price } \\
\hline Functions & $\mathrm{R}^{2}$ & F-test & Signif. & $\mathrm{K}$ & $\mathrm{a}$ & $\mathrm{b}$ & c \\
\hline Linear & 0.0346 & 37.298 & 0.0561 & 72.860 & 0.0015 & & \\
\hline Logarithmic & 0.0747 & 84.044 & 0.0045 & 55.435 & 0.4220 & & \\
\hline Inverse & 0.0799 & 90.415 & 0.0033 & 78.788 & -344.059 & & \\
\hline Quadratic & 0.0690 & 38.186 & 0.0251 & 69.774 & 0.0051 & $-4.23 \times 10^{-3}$ & \\
\hline Cubic & 0.0721 & 26.451 & 0.0531 & 68.060 & 0.0085 & $-1.89 \times 10^{-2}$ & $1.16 \times 10^{-5}$ \\
\hline \multicolumn{8}{|c|}{ Independent variable: Maximum price } \\
\hline Functions & $\mathrm{R}^{2}$ & F-test & Signif. & K & a & $\mathrm{b}$ & c \\
\hline Linear & 0.0695 & 77.681 & 0.0063 & 70.803 & 0.0028 & & \\
\hline Logarithmic & 0.0714 & 79.978 & 0.0056 & 54.294 & 0.4258 & & \\
\hline Inverse & 0.0640 & 71.174 & 0.0088 & 78.090 & -359.920 & & \\
\hline Quadratic & 0.0713 & 39.542 & 0.0221 & 69.816 & 0.0040 & $-2.91 \times 10^{-3}$ & \\
\hline Cubic & 0.0720 & 26.390 & 0.0535 & 70.837 & 0.0020 & $7.32 \times 10^{-3}$ & $-1.37 \times 10^{-5}$ \\
\hline \multicolumn{8}{|c|}{ Season: High } \\
\hline \multicolumn{8}{|c|}{ Independent variable: Minimum price } \\
\hline Functions & $R^{2}$ & F-test & Signif. & $\mathrm{K}$ & a & $\mathrm{b}$ & c \\
\hline Linear & 0.1276 & 118.521 & 0.0009 & 70.786 & 0.0025 & & \\
\hline Logarithmic & 0.1789 & 176.581 & 0.0000 & 49.975 & 0.5133 & & \\
\hline Inverse & 0.1426 & 134.739 & 0.0004 & 78.557 & -381.228 & & \\
\hline Quadratic & 0.1856 & 91.215 & 0.0002 & 66.801 & 0.0070 & $-7.98 \times 10^{-3}$ & \\
\hline Cubic & 0.1926 & 62.840 & 0.0007 & 64.847 & 0.0104 & $-2.24 \times 10^{-2}$ & $1.49 \times 10^{-5}$ \\
\hline \multicolumn{8}{|c|}{ Independent variable: Maximum price } \\
\hline Functions & $R^{2}$ & F-test & Signif. & K & $\mathrm{a}$ & $\mathrm{b}$ & c \\
\hline Linear & 0.1535 & 146.982 & 0.0002 & 70.116 & 0.0024 & & \\
\hline Logarithmic & 0.1772 & 174.486 & 0.0000 & 49.230 & 0.5052 & & \\
\hline Inverse & 0.1276 & 118.478 & 0.0009 & 78.165 & -423.641 & & \\
\hline Quadratic & 0.1841 & 90.263 & 0.0002 & 66.889 & 0.0055 & $-5.20 \times 10^{-3}$ & \\
\hline Cubic & 0.1841 & 59.430 & 0.0010 & 66.774 & 0.0057 & $-5.94 \times 10^{-3}$ & $7.42 \times 10^{-7}$ \\
\hline
\end{tabular}


Table 2. Regression analysis in 4 and 5 stars, with service quality average $(Q)$ as dependent variable.

\begin{tabular}{|c|c|c|c|c|c|c|c|}
\hline \multicolumn{8}{|c|}{ Season: Low } \\
\hline \multicolumn{8}{|c|}{ Independent variable: Minimum price } \\
\hline Functions & $\mathrm{R}^{2}$ & F-test & Signif. & K & $\mathrm{a}$ & $\mathrm{b}$ & c \\
\hline Linear & 0.1256 & 149.486 & 0.0001 & 77.573 & 0.0032 & & \\
\hline Logarithmic & 0.2919 & 428.912 & $2.25 \times 10^{-6}$ & 38.876 & 0.9341 & & \\
\hline Inverse & 0.2912 & 427.317 & $2.38 \times 10^{-6}$ & 90.236 & -735.271 & & \\
\hline Quadratic & 0.2879 & 208.294 & $2.53 \times 10^{-5}$ & 70.066 & 0.0121 & $-1.03 \times 10^{-2}$ & \\
\hline Cubic & 0.2926 & 140.677 & $9.62 \times 10^{-5}$ & 67.726 & 0.0167 & $-3.03 \times 10^{-2}$ & $1.59 \times 10^{-5}$ \\
\hline \multicolumn{8}{|c|}{ Independent variable: Maximum price } \\
\hline Functions & $\mathrm{R}^{2}$ & F-test & Signif. & $\mathrm{K}$ & $\mathrm{a}$ & $\mathrm{b}$ & c \\
\hline Linear & 0.2746 & 393.837 & $8.14 \times 10^{-6}$ & 72.839 & 0.0062 & & \\
\hline Logarithmic & 0.2962 & 437.721 & $1.64 \times 10^{-6}$ & 34.979 & 0.9713 & & \\
\hline Inverse & 0.2524 & 351.286 & $4.05 \times 10^{-5}$ & 89.053 & -800.313 & & \\
\hline Quadratic & 0.2840 & 204.319 & $3.36 \times 10^{-5}$ & 70.320 & 0.0094 & $-7.43 \times 10^{-3}$ & \\
\hline Cubic & 0.2883 & 137.759 & $1.30 \times 10^{-4}$ & 67.530 & 0.0149 & $-3.54 \times 10^{-2}$ & $3.74 \times 10^{-5}$ \\
\hline \multicolumn{8}{|c|}{ Season: High } \\
\hline \multicolumn{8}{|c|}{ Independent variable: Minimum price } \\
\hline Functions & $R^{2}$ & F-test & Signif. & $\mathrm{K}$ & $a$ & $\mathrm{~b}$ & c \\
\hline Linear & 0.3169 & 375.928 & $3.02 \times 10^{-5}$ & 73.857 & 0.0048 & & \\
\hline Logarithmic & 0.4851 & 763.286 & $2.64 \times 10^{-10}$ & 32.700 & 10.070 & & \\
\hline Inverse & 0.3947 & 528.210 & $2.04 \times 10^{-7}$ & 88.854 & -755.736 & & \\
\hline Quadratic & 0.5341 & 458.708 & $5.35 \times 10^{-11}$ & 64.673 & 0.0151 & $-1.84 \times 10^{-2}$ & \\
\hline Cubic & 0.5366 & 304.979 & $3.37 \times 10^{-10}$ & 63.290 & 0.0175 & $-2.86 \times 10^{-2}$ & $1.06 \times 10^{-5}$ \\
\hline \multicolumn{8}{|c|}{ Independent variable: Maximum price } \\
\hline Functions & $\mathrm{R}^{2}$ & F-test & Signif. & K & a & $\mathrm{b}$ & c \\
\hline Linear & 0.3722 & 480.355 & $9.17 \times 10^{-7}$ & 72.703 & 0.0044 & & \\
\hline Logarithmic & 0.4622 & 696.399 & $1.57 \times 10^{-9}$ & 32.191 & 0.9724 & & \\
\hline Inverse & 0.3450 & 426.806 & $5.29 \times 10^{-6}$ & 87.997 & -830.166 & & \\
\hline Quadratic & 0.4791 & 367.926 & $4.67 \times 10^{-9}$ & 65.509 & 0.0114 & $-1.16 \times 10^{-2}$ & \\
\hline Cubic & 0.4792 & 242.302 & $3.23 \times 10^{-8}$ & 65.811 & 0.0109 & $-9.69 \times 10^{-3}$ & $-1.94 \times 10^{-6}$ \\
\hline
\end{tabular}

Table 3. Regression analysis in 4 and 5 stars, with added value as dependent variable.

\begin{tabular}{|c|c|c|c|c|c|c|c|}
\hline \multicolumn{8}{|c|}{ Season: Low } \\
\hline \multicolumn{8}{|c|}{ Independent variable: Minimum price } \\
\hline Functions & $\mathrm{R}^{2}$ & F-test & Signif. & K & a & $\mathrm{b}$ & c \\
\hline Linear & 0.0811 & 91.855 & 0.0030 & -0.4556 & -0.0015 & & \\
\hline Logarithmic & 0.2234 & 299.300 & $3.11 \times 10^{-4}$ & 15.359 & -0.4771 & & \\
\hline Inverse & 0.2143 & 283.719 & $5.82 \times 10^{-4}$ & -10.786 & 368.329 & & \\
\hline Quadratic & 0.2123 & 138.813 & $4.59 \times 10^{-3}$ & -0.0616 & -0.0062 & $5.40 \times 10^{-3}$ & \\
\hline Cubic & 0.2609 & 120.051 & $8.54 \times 10^{-4}$ & 0.3786 & -0.0147 & $4.31 \times 10^{-2}$ & $-2.99 \times 10^{-5}$ \\
\hline \multicolumn{8}{|c|}{ Independent variable: Maximum price } \\
\hline Functions & $\mathrm{R}^{2}$ & F-test & Signif. & K & $\mathrm{a}$ & $\mathrm{b}$ & c \\
\hline Linear & 0.1919 & 246.971 & $2.65 \times 10^{-3}$ & -0.2178 & -0.0030 & & \\
\hline Logarithmic & 0.2626 & 370.530 & $1.95 \times 10^{-5}$ & 19.152 & -0.5341 & & \\
\hline Inverse & 0.2154 & 285.666 & $5.38 \times 10^{-4}$ & -10.499 & 431.722 & & \\
\hline Quadratic & 0.2763 & 196.686 & $5.82 \times 10^{-5}$ & 0.2236 & -0.0086 & $1.30 \times 10^{-2}$ & \\
\hline Cubic & 0.2840 & 134.866 & $1.76 \times 10^{-4}$ & 0.4408 & -0.0129 & $3.48 \times 10^{-2}$ & $-2.91 \times 10^{-5}$ \\
\hline \multicolumn{8}{|c|}{ Season: High } \\
\hline \multicolumn{8}{|c|}{ Independent variable: Minimum price } \\
\hline Functions & $\mathrm{R}^{2}$ & F-test & Signif. & $\mathrm{K}$ & $\mathrm{a}$ & $\mathrm{b}$ & c \\
\hline Linear & 0.0943 & 84.370 & 0.0047 & -0.4155 & -0.0014 & & \\
\hline Logarithmic & 0.2258 & 236.280 & $5.64 \times 10^{-3}$ & 12.027 & -0.3823 & & \\
\hline Inverse & 0.2196 & 228.048 & $7.86 \times 10^{-3}$ & -0.9560 & 313.714 & & \\
\hline Quadratic & 0.3177 & 186.295 & $2.28 \times 10^{-4}$ & 0.1027 & -0.0072 & $1.04 \times 10^{-2}$ & \\
\hline Cubic & 0.3246 & 126.562 & $7.74 \times 10^{-4}$ & 0.2312 & -0.0095 & $1.99 \times 10^{-2}$ & $-9.82 \times 10^{-9}$ \\
\hline \multicolumn{8}{|c|}{ Independent variable: Maximum price } \\
\hline Functions & $R^{2}$ & F-test & Signif. & $\mathrm{K}$ & $\mathrm{a}$ & $\mathrm{b}$ & c \\
\hline Linear & 0.1190 & 109.482 & 0.0013 & -0.3710 & -0.0014 & & \\
\hline Logarithmic & 0.2286 & 240.040 & $4.85 \times 10^{-3}$ & 12.792 & -0.3804 & & \\
\hline Inverse & 0.2049 & 208.811 & 0.0000 & -0.9298 & 355.984 & & \\
\hline Quadratic & 0.3029 & 173.829 & $5.38 \times 10^{-4}$ & 0.1540 & -0.0065 & $8.47 \times 10^{-3}$ & \\
\hline Cubic & 0.3048 & 115.476 & $2.35 \times 10^{-3}$ & 0.2329 & -0.0077 & $1.35 \times 10^{-2}$ & $-5.07 \times 10^{-6}$ \\
\hline
\end{tabular}




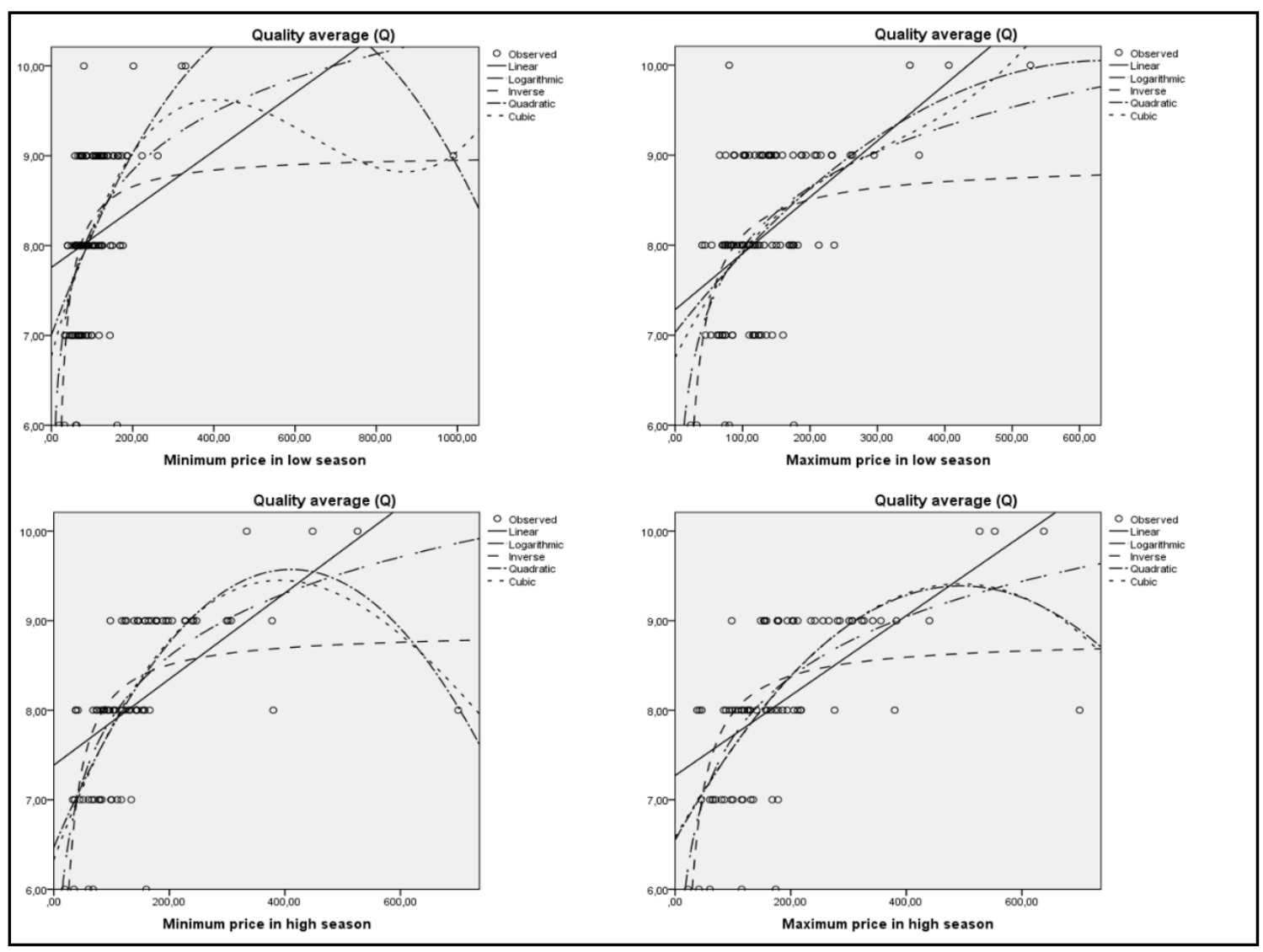

Figure 1. Functions of the regression analysis with better fit in lodgings with 4 and 5 stars.

\subsection{Lodgings with 3 Stars or Less}

Lodgings with 3 stars or less present less consistent results due to a greater disparity in commercial and pricing strategies, as Tables $4-6$ show. The $R^{2}$ adjusted for the perceived value variable are very low, around zero, which shows that there is no relationship with the different types of prices. Likewise, the average quality of service perceived obtained poor results, highlighting the cubic function, which obtained an $\mathrm{R}^{2}$ adjusted of 0.1197 for the lowest prices in low season and 0.0948 for the maximum prices in low season. As far as high season prices are concerned, the results improve significantly in the cubic function, obtaining an $\mathrm{R}^{2}$ adjusted of 0.1720 for minimum prices and 0.1329 for maximum prices.

In this type of lodging, there are a large variety of prices and marketing strategies, leading to very significant differences. The added value variable presents superior results to the other constructs studied (see Table 6). For low season minimum prices, the inverse function obtains the best fit $(0.1522)$, followed by the cubic function (0.1453). The same trend can be seen for maximum prices in low season, where the inverse function is again the best $R^{2}$ adjusted (0.1484) but on this occasion, the cubic (0.1359), quadratic (0.1336) and logarithmic (0.1317) functions have similar fits. The minimum prices in high season are most related to added value because the cubic function obtains an $R^{2}$ adjusted of 0.2132 and the quadratic function obtains an $R^{2}$ adjusted of 0.2113 . Likewise, for maximum prices in high season, the cubic function reaches the best fit (0.2047), followed by the quadratic function (0.2019). Figure 2 shows the functions analysed that are related to prices and added value, as this variable obtained the best fit in all the regressions carried out.

The results from this study show that prices should be analysed according to the type of lodging category. It can be seen that, as there is a higher price for higher category lodgings, the main differential factor is the quality of the average perceived service. This means that customers appreciate significant differences in the quality of the service offered by higher category lodging, whereas the added value 
obtains a lower fit because the price is already high and does not make a greater difference than the quality of the service. Conversely, when the lodging category decreases, there is a greater effect of differentiation in prices, which means that the fit obtained for the quality of service is lower than for added value. Therefore, it can be concluded that the degree of differentiation of lodgings in a particular tourist destination will determine the online reputation variable that fits best. If the sample shows a greater concentration in the marketing and pricing strategy applied, quality of service will be the main differentiating factor. However, if there is a great disparity between the pricing policy and the commercial strategy, the added value will achieve a better fit in relation to lodging prices.

Table 4. Regression analysis in 3 stars or less, with value as dependent variable.

\begin{tabular}{|c|c|c|c|c|c|c|c|}
\hline \multicolumn{8}{|c|}{ Season: Low } \\
\hline \multicolumn{8}{|c|}{ Independent variable: Minimum price } \\
\hline Functions & $\mathrm{R}^{2}$ & F-test & Signif. & $\mathrm{K}$ & $\mathrm{a}$ & $\mathrm{b}$ & c \\
\hline Linear & $5.10 \times 10^{-2}$ & 0.0088 & 0.9250 & 76.569 & 0.0001 & & \\
\hline Logarithmic & 0.0016 & 0.2863 & 0.5932 & 74.165 & 0.0639 & & \\
\hline Inverse & 0.0049 & 0.8726 & 0.3515 & 77.907 & -55.748 & & \\
\hline Quadratic & $8.92 \times 10^{-2}$ & 0.0077 & 0.9923 & 76.462 & 0.0004 & $-1.03 \times 10^{-3}$ & \\
\hline Cubic & 0.0238 & 13.979 & 0.2451 & 72.051 & 0.0171 & -0.0001 & $3.30 \times 10^{-4}$ \\
\hline \multicolumn{8}{|c|}{ Independent variable: Maximum price } \\
\hline Functions & $R^{2}$ & F-test & Signif. & K & $\mathrm{a}$ & $\mathrm{b}$ & c \\
\hline Linear & 0.0002 & 0.0403 & 0.8410 & 76.820 & -0.0002 & & \\
\hline Logarithmic & 0.0006 & 0.1128 & 0.7373 & 75.229 & 0.0352 & & \\
\hline Inverse & 0.0047 & 0.8334 & 0.3625 & 77.680 & -50.848 & & \\
\hline Quadratic & 0.0002 & 0.0241 & 0.9761 & 76.715 & $-1.13 \times 10^{-2}$ & $-1.05 \times 10^{-3}$ & \\
\hline Cubic & 0.0380 & 22.689 & 0.0822 & 71.054 & 0.0206 & -0.0001 & $3.84 \times 10^{-4}$ \\
\hline \multicolumn{8}{|c|}{ Season: High } \\
\hline \multicolumn{8}{|c|}{ Independent variable: Minimum price } \\
\hline Functions & $R^{2}$ & F-test & Signif. & $\mathrm{K}$ & a & $\mathrm{b}$ & c \\
\hline Linear & $9.90 \times 10^{-3}$ & 0.0012 & 0.9716 & 76.579 & $4.13 \times 10^{-2}$ & & \\
\hline Logarithmic & 0.0042 & 0.5505 & 0.4594 & 71.954 & 0.1073 & & \\
\hline Inverse & 0.0111 & 14.450 & 0.2315 & 78.488 & -132.101 & & \\
\hline Quadratic & 0.0141 & 0.9098 & 0.4051 & 74.252 & 0.0038 & $-9.22 \times 10^{-3}$ & \\
\hline Cubic & 0.0148 & 0.6326 & 0.5952 & 73.393 & 0.0059 & $-2.27 \times 10^{-2}$ & $1.97 \times 10^{-5}$ \\
\hline \multicolumn{8}{|c|}{ Independent variable: Maximum price } \\
\hline Functions & $\mathrm{R}^{2}$ & F-test & Signif. & $\mathrm{K}$ & a & $\mathrm{b}$ & c \\
\hline Linear & 0.0008 & 0.1035 & 0.7481 & 76.953 & -0.0003 & & \\
\hline Logarithmic & 0.0008 & 0.1122 & 0.7381 & 74.599 & 0.0453 & & \\
\hline Inverse & 0.0062 & 0.8000 & 0.3727 & 77.867 & -95.891 & & \\
\hline Quadratic & 0.0091 & 0.5848 & 0.5586 & 75.285 & 0.0022 & $-6.62 \times 10^{-2}$ & \\
\hline Cubic & 0.0131 & 0.5614 & 0.6414 & 73.143 & 0.0074 & $-3.80 \times 10^{-2}$ & $4.53 \times 10^{-5}$ \\
\hline
\end{tabular}

Table 5. Regression analysis in 3 stars or less with service quality average (Q) as dependent variable.

\begin{tabular}{|c|c|c|c|c|c|c|c|}
\hline \multicolumn{8}{|c|}{ Season: Low } \\
\hline \multicolumn{8}{|c|}{ Independent variable: Minimum price } \\
\hline Functions & $\mathrm{R}^{2}$ & F-test & Signif. & $\mathrm{K}$ & $\mathrm{a}$ & $\mathrm{b}$ & c \\
\hline Linear & 0.0127 & 22.384 & 0.1364 & 74.738 & 0.0024 & & \\
\hline Logarithmic & 0.0625 & 116.047 & 0.0008 & 59.391 & 0.4300 & & \\
\hline Inverse & 0.1026 & 198.940 & $1.46 \times 10^{-2}$ & 82.304 & -275.463 & & \\
\hline Quadratic & 0.0789 & 74.184 & 0.0008 & 69.887 & 0.0149 & $-4.68 \times 10^{-2}$ & \\
\hline Cubic & 0.1197 & 78.010 & $6.51 \times 10^{-2}$ & 63.584 & 0.0389 & -0.0002 & $4.72 \times 10^{-4}$ \\
\hline \multicolumn{8}{|c|}{ Independent variable: Maximum price } \\
\hline Functions & $\mathrm{R}^{2}$ & F-test & Signif. & $\mathrm{K}$ & $\mathrm{a}$ & $\mathrm{b}$ & c \\
\hline Linear & 0.0175 & 31.161 & 0.0792 & 74.436 & 0.0025 & & \\
\hline Logarithmic & 0.0575 & 106.273 & 0.0013 & 61.520 & 0.3622 & & \\
\hline Inverse & 0.0915 & 175.432 & $4.46 \times 10^{-2}$ & 81.013 & -2.428 .766 & & \\
\hline Quadratic & 0.0682 & 63.378 & 0.0022 & 70.670 & 0.0117 & $-3.76 \times 10^{-2}$ & \\
\hline Cubic & 0.0948 & 60.066 & 0.0006 & 65.499 & 0.0306 & -0.0002 & $3.51 \times 10^{-4}$ \\
\hline
\end{tabular}


Table 5. Cont.

\begin{tabular}{|c|c|c|c|c|c|c|c|}
\hline \multicolumn{8}{|c|}{ Season: High } \\
\hline \multicolumn{8}{|c|}{ Independent variable: Minimum price } \\
\hline Functions & $\mathrm{R}^{2}$ & F-test & Signif. & K & a & $\mathrm{b}$ & c \\
\hline Linear & 0.0005 & 0.0711 & 0.7901 & 76.171 & 0.0003 & & \\
\hline Logarithmic & 0.0432 & 57.904 & 0.0175 & 60.314 & 0.3718 & & \\
\hline Inverse & 0.0903 & 127.099 & 0.0005 & 82.268 & -409.564 & & \\
\hline Quadratic & 0.1458 & 108.454 & $4.48 \times 10^{-2}$ & 68.031 & 0.0136 & $-3.22 \times 10^{-2}$ & \\
\hline Cubic & 0.1720 & 87.290 & $2.64 \times 10^{-2}$ & 62.357 & 0.0278 & -0.0001 & $1.30 \times 10^{-4}$ \\
\hline \multicolumn{8}{|c|}{ Independent variable: Maximum price } \\
\hline Functions & $R^{2}$ & F-test & Signif. & $\mathrm{K}$ & a & $\mathrm{b}$ & c \\
\hline Linear & 0.0013 & 0.1730 & 0.6780 & 75.985 & 0.0004 & & \\
\hline Logarithmic & 0.0354 & 47.021 & 0.0319 & 62.491 & 0.3145 & & \\
\hline Inverse & 0.0697 & 95.919 & 0.0024 & 81.034 & $-35.0146 c ̧$ & & \\
\hline Quadratic & 0.1211 & 87.539 & 0.0002 & 69.087 & 0.0112 & $-2.74 \times 10^{-2}$ & \\
\hline Cubic & 0.1329 & 64.403 & 0.0004 & 65.110 & 0.0208 & $-8.56 \times 10^{-2}$ & $8.40 \times 10^{-5}$ \\
\hline
\end{tabular}

Table 6. Regression analysis in 3 stars or less, with added value as dependent variable.

\begin{tabular}{|c|c|c|c|c|c|c|c|}
\hline \multicolumn{8}{|c|}{ Season: Low } \\
\hline \multicolumn{8}{|c|}{ Independent variable: Minimum price } \\
\hline Functions & $\mathrm{R}^{2}$ & F-test & Signif. & $\mathrm{K}$ & $\mathrm{a}$ & $\mathrm{b}$ & c \\
\hline Linear & 0.0551 & 101.514 & 0.0017 & 0.2061 & -0.0032 & & \\
\hline Logarithmic & 0.1219 & 241.742 & $2.02 \times 10^{-3}$ & 15.109 & -0.3820 & & \\
\hline Inverse & 0.1522 & 312.601 & $8.59 \times 10^{-5}$ & -0.4539 & 213.449 & & \\
\hline Quadratic & 0.1260 & 124.763 & $8.68 \times 10^{-3}$ & 0.5252 & -0.0114 & $3.08 \times 10^{-2}$ & \\
\hline Cubic & 0.1453 & 97.476 & $5.65 \times 10^{-3}$ & 0.8007 & -0.0219 & 0.0001 & $-2.06 \times 10^{-4}$ \\
\hline \multicolumn{8}{|c|}{ Independent variable: Maximum price } \\
\hline Functions & $\mathrm{R}^{2}$ & F-test & Signif. & $\mathrm{K}$ & $\mathrm{a}$ & $\mathrm{b}$ & c \\
\hline Linear & 0.0840 & 159.709 & $9.49 \times 10^{-2}$ & 0.2568 & -0.0035 & & \\
\hline Logarithmic & 0.1317 & 263.987 & $7.40 \times 10^{-4}$ & 14.291 & -0.3485 & & \\
\hline Inverse & 0.1484 & 303.328 & $1.29 \times 10^{-4}$ & -0.3710 & 196.661 & & \\
\hline Quadratic & 0.1336 & 133.411 & $4.09 \times 10^{-3}$ & 0.4936 & -0.0093 & $2.37 \times 10^{-2}$ & \\
\hline Cubic & 0.1359 & 90.175 & $1.40 \times 10^{-2}$ & 0.5900 & -0.0128 & $5.50 \times 10^{-2}$ & $-6.54 \times 10^{-5}$ \\
\hline \multicolumn{8}{|c|}{ Season: High } \\
\hline \multicolumn{8}{|c|}{ Independent variable: Minimum price } \\
\hline Functions & $\mathrm{R}^{2}$ & F-test & Signif. & $\mathrm{K}$ & a & $\mathrm{b}$ & c \\
\hline Linear & 0.0169 & 22.111 & 0.1394 & 0.1349 & -0.0011 & & \\
\hline Logarithmic & 0.0891 & 125.315 & 0.0005 & 14.317 & -0.3208 & & \\
\hline Inverse & 0.1182 & 171.599 & $6.20 \times 10^{-2}$ & -0.3608 & 281.650 & & \\
\hline Quadratic & 0.2113 & 170.208 & $2.82 \times 10^{-4}$ & 0.7008 & -0.0104 & $2.24 \times 10^{-2}$ & \\
\hline Cubic & 0.2132 & 113.835 & $1.17 \times 10^{-2}$ & 0.7916 & -0.0126 & $3.66 \times 10^{-2}$ & $-2.08 \times 10^{-5}$ \\
\hline \multicolumn{8}{|c|}{ Independent variable: Maximum price } \\
\hline Functions & $\mathrm{R}^{2}$ & F-test & Signif. & $\mathrm{K}$ & $\mathrm{a}$ & $\mathrm{b}$ & c \\
\hline Linear & 0.0331 & 43.941 & 0.0380 & 0.1802 & -0.0014 & & \\
\hline Logarithmic & 0.0973 & 138.024 & 0.0003 & 14.303 & -0.3134 & & \\
\hline Inverse & 0.1087 & 156.120 & 0.0001 & -0.3048 & 262.839 & & \\
\hline Quadratic & 0.2019 & 160.716 & $6.00 \times 10^{-4}$ & 0.6724 & -0.0091 & $1.95 \times 10^{-2}$ & \\
\hline Cubic & 0.2047 & 108.111 & $2.27 \times 10^{-3}$ & 0.5572 & -0.0064 & $2.68 \times 10^{-3}$ & $2.43 \times 10^{-5}$ \\
\hline
\end{tabular}




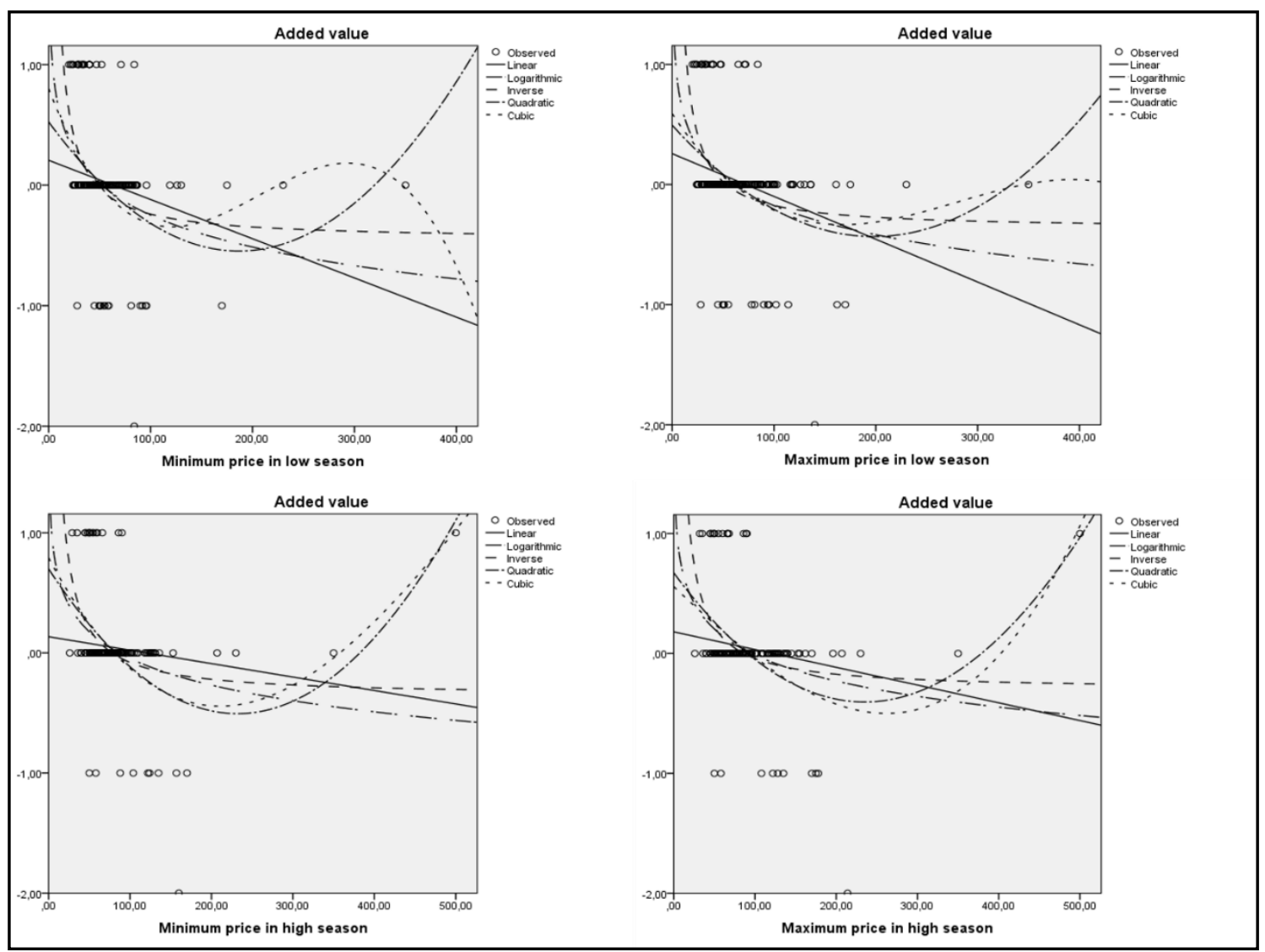

Figure 2. Functions of the regression analysis with better fit in lodgings with 3 stars or less.

\section{Discussion and Conclusions}

\subsection{Discussion}

The study allows us to establish a possible methodology that can be used by accommodation companies to establish their pricing strategy. One of the principal problems they have lies in identify whether the prices are aligned with the levels of competitiveness existing on the market. Likewise, the constant price updating dynamics that tourism companies engage in based on demand and online reputation show that revenue management has increased its scope of influence beyond price and is combined with updating the marketing strategy.

The current reality is conditioned by the opinions customers share on the Internet, which directly influence the purchasing behaviour of users. In this regard, the demand for lodging depends to a large extent on the online reputation, as well as the price level established. The main constructs that are quantitatively evaluated on web pages specialized in customer opinions are the perceived value and the quality of the service perceived. In addition, added value is determined by these other two constructs and has been demonstrated to have a close relationship with price levels.

Therefore, the online reputation measured through these constructs produces a flow of information that influences customer decisions and, consequently, the lodgings' competitiveness level. Customers can obtain and analyse information about all the possible options for their holidays and they are able to compare the prices and value provided by different lodgings. This study focuses on this point, with the objective of determining which online reputation variables are most related to the different price levels offered by accommodations located in a tourist destination.

The lodging category involves an initial segmentation of the market that is reflected in prices. In higher categories, the accommodation will tend to increase its prices because it offers a higher level of service quality. For this reason, the study has differentiated between two large groups of lodgings: 
on the one hand, those with 4 or 5 stars and, on the other, those with 3 stars or less. Thus, it was possible to study whether the fit obtained in the regressions is similar in terms of the type of function and the variables analysed.

The results confirm differences between the clusters of lodging categories studied. They demonstrate that higher category accommodations obtain a better fit, with cubic, quadratic and logarithmic functions showing a higher relationship between prices and the online reputation variables analysed. In relation to the variables, the perceived value is not significantly related to the price, whereas the average perceived quality of service obtains the best $R^{2}$ adjusted. The added value also achieves satisfactory results but in these categories it does not reach the results obtained by quality of service.

The study shows that, when analysing the highest category of lodgings, the average quality of service perceived is what determines companies' competitiveness. That is, because these firms maintain less differentiated price levels, customer ratings of the quality of service received are linked to the level of prices paid. Different results are obtained by lodgings with 3 stars or less, where cubic and quadratic functions obtain the best fit but without reaching those obtained by higher category lodgings. It is observed that lower category lodgings follow different pricing policies and marketing strategies, which leads to added value being the variable that obtains the best results.

These results show that the category of accommodations determines different pricing behaviours, as the most related online reputation variables differ according to the number of stars. In the debate proposed by López Fernandez [23] and O'Connor [24], it can be stated that to a large extent the quality of service is related to the category of accommodation. On the other hand, it is also demonstrated that the added value variable proposed by Rodríguez-Díaz et al. [13], is very useful for establishing the relationship between online reputation and accommodation prices. In this line, as the offer diversifies, as happens with establishments of 3 stars or less, the added value shows to be the most suitable variable to analyse prices.

Prices are directly related to the revenue management applied by the accommodations [1,32], so it can be said that, depending on the results obtained, the revenue management is directly related to the online reputation. These results open up a new panorama when it comes to defining pricing strategy, since it is shown that online reputation has an impact on the price level that the customer is willing to pay [20,29]. On the other hand, it is important to adjust the quality of the service aimed at building customer loyalty to the revenue obtained, which could constitute a source of conflict in the accommodation strategy [22].

In order to address the complexity involved in defining and constantly updating the pricing policy for lodging and to maintain a competitive level that guarantees a demand that generates the desired income, it is necessary to develop systems of learning machines and artificial intelligence [86-88]. From this perspective, the methodology proposed and validated in this study may be tested for the development of this type of tools based on Big Data and models of competitive dynamics that are constantly changing. To the extent that online reputation based on customer feedback influences lodging prices, it is necessary to have tools and algorithms that automatically respond to changes in demand, online reputation and competitors' prices. These algorithms must have limits on price offerings that do not produce irreversible effects on accommodation performance in highly volatile environments. One aspect to highlight in this study is that the type of mathematical function and online reputation variables that best explain prices may vary depending on the category of accommodations. This result should be considered in the development of algorithms for predicting demand and setting prices, because depending on changes in the competitive environment the function or variables may be modified to obtain a better fit.

\subsection{Conclusions}

The procedure followed in this study has been shown to be valid for determining the prices lodgings should establish in a competitive environment. Furthermore, it is a line of research that can help to develop automated improvements in the pricing of tourist accommodations according 
to their level of demand, category, type of price function and online reputation. It has been shown that online reputation is directly related to the price level of accommodation and, depending on the category, the variables that best adjust are the perceived quality of service and added value. The original contribution of this study is to demonstrate that online reputation is directly related to prices in the study carried out and, consequently, to the revenue management of accommodations. Another contribution is to demonstrate that different functions can be used to relate prices to online reputation. In this context, the proposed methodology can be used to define models for simplifying the pricing decisions of accommodation managers as well as models of learning machines and artificial intelligence aimed at automatically making decisions with a large amount of data from the Internet.

This study has some limitations. It was carried out at a certain point in time and it focused on lodgings in three tourist destinations. Future research should assess whether price changes in other time periods maintain the same types of relations between prices and online reputation, whether the functions analysed continue to explain this relationship and whether the application of this methodology can also be extended to other tourist destinations with different characteristics. Other types of functions can also be explored but considering that the added value takes on a negative score, which implies a restriction of the functions to be studied. In any case, the development of automated methods or artificial intelligence applied to price setting in tourist lodgings must take into account the procedure followed in this study. In this context, the dynamics of tourist markets produce a constant updating of prices and online customer ratings, which implies constantly updating the analysis of the price functions that best explain the behaviour of the market at any given time, as well as the online reputation variables with the greatest influence.

Author Contributions: The authors have contributed equally in the research design and development, the data analysis and the writing of the paper. The authors have read and approved the final manuscript.

Funding: This research received no external funding.

Conflicts of Interest: The authors declare no conflicts of interest.

\section{References}

1. Abrate, G.; Viglia, G. Strategic and tactical decisions in hotel revenue management. Tour. Manag. 2016, 55, 123-132. [CrossRef]

2. Kim, W.G.; Park, S.A. Social media review rating versus traditional customer satisfaction: Which one has more incremental predictive power in explaining hotel performance? Int. J. Contemp. Hosp. Manag. 2017, 29, 784-802. [CrossRef]

3. Govers, R.; Go, F.M.; Kumar, K. Promoting Tourism Destination Image. J. Travel Res. 2007, 46, 15-23. [CrossRef]

4. Lai, K.; Li, X. Tourism destination image: Conceptual problems and definitional solutions. J. Travel Res. 2016, 55, 1065-1080. [CrossRef]

5. Sancho Esper, F; Álvarez Rateike, J. Tourism destination image and motivations: The Spanish perspective of Mexico. J. Travel Tour. Mark. 2010, 27, 349-360. [CrossRef]

6. Ye, Q.; Li, H.; Wang, Z.; Law, R. The influence of hotel price on perceived service quality and value in e-tourism: An empirical investigation based on online traveller reviews. J. Hosp. Tour. Res. 2014, 38, 23-39. [CrossRef]

7. Therkelsen, A. Imagining places: Image formation of tourists and its consequences for destination promotion. Scand. J. Hosp. Tour. 2003, 3, 134-150. [CrossRef]

8. Yacouel, N.; Fleischer, A. The role of cybermediaries in reputation building and price premiums in the online hotel market. J. Travel Res. 2012, 51, 219-226. [CrossRef]

9. Chun, R. Corporate reputation: Meaning and measurement. Int. J. Manag. Rev. 2005, 7, 91-109. [CrossRef]

10. Hernández Estárico, E.; Fuentes Medina, M.; Morini Marrero, S. Una aproximación a la reputación en línea de los establecimientos hoteleros españoles. Pap. Tur. 2012, 52, 63-88.

11. Rodríguez-Díaz, M.; Rodríguez-Díaz, R.; Rodríguez-Voltes, A.C.; Rodríguez-Voltes, C.I. A model of market positioning of destinations based on online customer reviews of lodgings. Sustainability 2018, 10, 78. 
12. Rodríguez-Díaz, M.; Rodríguez-Díaz, R.; Espino-Rodríguez, T.F. Analysis of the online reputation based on customer ratings of lodgings in tourism destinations. Adm. Sci. 2018, 8, 51. [CrossRef]

13. Rodríguez Díaz, M.; Espino Rodríguez, T.F.; Rodríguez Díaz, R. A model of market positioning based on value creation and service quality in the lodging industry: An empirical application of online customer reviews. Tour. Econ. 2015, 21, 1273-1294. [CrossRef]

14. Torres, E.N. Deconstructing service quality and customer satisfaction: Challenges and directions for future research. J. Hosp. Mark. Manag. 2014, 23, 652-677. [CrossRef]

15. Hooley, G.; Broderick, A.; Möller, K. Competitive positioning and the resource-based view of the firm. J. Strateg. Mark. 1998, 6, 97-116. [CrossRef]

16. Lovelock, C. Services Marketing; Prentice Hall: Englewood Cliffs, NJ, USA, 1991.

17. Hung, W.T.; Shang, J.K.; Wang, F.C. Pricing determinants in the hotel industry: Quantile regression analysis. Int. J. Hosp. Manag. 2010, 29, 378-384. [CrossRef]

18. Masiero, L.; Nicolau, J. Tourism market segmentation based on Price sensitivity: Finding similar price preferences on tourism activities. J. Travel Res. 2012, 51, 426-435. [CrossRef]

19. Israeli, A.A. Star rating and corporate affiliation: Their influence on room price and performance of hotels in Israel. Int. J. Hosp. Manag. 2002, 21, 405-424. [CrossRef]

20. Tanford, S.; Baloglu, S.; Erdem, M. Travel packaging on the Internet: The impact of pricing information and perceived value on consumer choice. J. Travel Res. 2012, 5, 68-80. [CrossRef]

21. Rhee, H.T.; Yang, S.B. Does hotel attribute importance differ by hotel? Focusing on hotel-classifications and customers' overall ratings. Computers in Human Behavior. 2015, 50, 576-587. [CrossRef]

22. Wang, X.L. Relationship or revenue: Potential management conflicts between customer relationship management and hotel revenue management. Int. J. Hosp. Manag. 2012, 12, 864-874. [CrossRef]

23. López Fernández, M.C.; Serrano Bedia, A.M. Is the hotel classification system a good indicator of hotel quality? An application in Spain. Tour. Manag. 2004, 25, 771-775. [CrossRef]

24. O'Connor, P. Managing a hotel's image on TripAdvisor. J. Hosp. Mark. Manag. 2010, 19, 754-772. [CrossRef]

25. Gallarza, M.G.; Saura, I.G. Value dimensions, perceived value, satisfaction and loyalty: An investigation of university students' travel behaviour. Tour. Manag. 2006, 27, 437-452. [CrossRef]

26. Gallarza, M.G.; Gil-Saura, I.; Holbrook, M.B. The value of value: Further excursions on the meaning and role of customer value. J. Consum. Behav. 2011, 10, 179-191. [CrossRef]

27. Rodríguez-Díaz, M.; Espino-Rodríguez, T.F. A methodology for a comparative analysis of the lodging tourism destinations based on online customer review. J. Destin. Mark. Manag. 2018, 8, 147-160. [CrossRef]

28. Rodríguez-Díaz, M.; Espino-Rodríguez, T.F. Determining the reliability and validity of online reputation databases for lodging: Booking.com, TripAdvisror, and HolidayCheck. J. Vacat. Mark. 2018, 24, 261-274. [CrossRef]

29. Luca, M. Reviews, Reputation, and Revenue: The Case of Yelp.com; Harvard Business School NOM Unit, Working Paper; Harvard Business School: Boston, MA, USA, 2011; pp. 12-16.

30. Noone, B.M.; McGuire, K.A.; Rohlfs, K.V. Social media meets hotel revenue management: Opportunities, issues and unanswered questions. J. Revenues Pricing Manag. 2011, 10, 293-305. [CrossRef]

31. Ye, Q.; Law, R.; Gu, B. The impact of online e user reviews on hotel room sales. J. Hosp. Manag. 2009, 28, 180-182. [CrossRef]

32. Noone, B.M.; Mattila, A.S. Hotel revenue management and the Internet: The effect of price presentation strategies on customers' willingness to book. Int. J. Hosp. Manag. 2009, 28, 272-279. [CrossRef]

33. Mattila, A.; O'Neill, J. Relationship between hotel room pricing, occupancy and guest satisfaction: A longitudinal case of a midscale hotel. J. Tour. Hosp. Res. 2003, 27, 328-341. [CrossRef]

34. Von Martens, T.; Hilbert, A. Customer-value-based revenue management. J. Revenue Pricing Manag. 2011, 10, 87-98. [CrossRef]

35. Conti, T. Planning for competitive customer value. TQM J. 2013, 25, 224-243. [CrossRef]

36. Jena, S.K.; Jog, D. Price competition in a tourism supply chain. Tour. Econ. 2017, 23, 1235-1254. [CrossRef]

37. Oh, H. Service quality, customer satisfaction, and customer value: A holistic perspective. Int. J. Hosp. Manag. 1999, 18, 67-82. [CrossRef]

38. Kim, K.; Oh, H. Customer satisfaction, service quality, and customer value: Years 2000-2015. Int. J. Contemp. Hosp. Manag. 2017, 29, 2-29. 
39. Cross, R.G.; Higbie, J.A.; Cross, D.Q. Revenue management's renaissance: A rebirth of the art and science of profitable revenue generation. Cornell Hosp. Q. 2009, 50, 56-81. [CrossRef]

40. Guillet, B.D.; Mohammed, I. Revenue management research in hospitality and tourism: A critical review of current literature and suggestions for future research. Int. J. Contemp. Hosp. Manag. 2015, 27, 526-560. [CrossRef]

41. Li, H.; Ye, Q.; Law, R. Determinants of customer satisfaction in the hotel industry: An application of online review analysis. Asia Pac. J. Tour. Res. 2013, 18, 784-802. [CrossRef]

42. Parasuraman, A.; Zeithaml, V.; Berry, L.L. SERVQUAL: A multiple-item scale for measuring customer perceptions of service quality. J. Retail. 1988, 64, 12-40.

43. Oliver, R.L. Satisfaction: A Behavioural Perspective on the Consumer; McGraw-Hill: New York, NY, USA, 1997.

44. Oh, $\mathrm{H}$. The effect of brand class, brand awareness, and price on customer value and behavioral intentions. J. Hosp. Tour. Res. 2000, 24, 136-162. [CrossRef]

45. Nasution, H.N.; Mavondo, F.T. Customer value in the hotel industry: What managers believe they deliver and what customer experience. Int. J. Hosp. Manag. 2008, 27, 204-213. [CrossRef]

46. Xie, K.L.; Zhang, Z.; Zhang, Z. The business value of online consumer reviews and management response to hotel performance. Int. J. Hosp. Manag. 2014, 43, 1-12. [CrossRef]

47. Sparks, B.; Butcher, K.; Bradley, G. Dimensions and correlates of consumer value: An application to the timeshare industry. Int. J. Hosp. Manag. 2008, 27, 98-108. [CrossRef]

48. Núñez-Serrano, J.A.; Turrion, J.; Velázquez, F.J. Are stars a good indicator of hotel quality? Assymetric information and regulatory heterogeneity in Spain. Tour. Manag. 2014, 42, 77-87. [CrossRef]

49. Lee, C.G. The determinants of hotel room rates: Another visit with Singapore's data. Int. J. Hosp. Manag. 2011, 30, 756-758. [CrossRef]

50. Lee, S.K.; Jang, S. Asymmetry of price competition in the lodging market. J. Travel Res. 2013, 52, 56-67. [CrossRef]

51. Croes, R.; Semrad, K.J. Does discounting work in the lodging industry? J. Travel Res. 2012, 51, 617-631. [CrossRef]

52. Blal, I.; Graf, N.S. The discount effect of non-normative physical characteristics on the price of lodging properties. Int. J. Hosp. Manag. 2013, 34, 413-422. [CrossRef]

53. Chen, C.M.; Lin, Y.C.; Tsai, Y.C. How does advertising affect the price elasticity of lodging demand? Evidence from Taiwan. Tour. Econ. 2015, 21, 1035-1045. [CrossRef]

54. Divisekera, S.; Kulendran, N. Economic effects of advertising on tourism demand: A case study. Tour. Econ. 2006, 12, 187-205. [CrossRef]

55. Kleinsasser, S.; Wagner, U. Price ending and tourism consumers' price perceptions. J. Retail. Consum. Serv. 2011, 18, 58-63. [CrossRef]

56. Masiero, L.; Nicolau, J. Price sensitivity to tourism activities: Looking for determinant factors. Tour. Econ. 2012, 18, 675-689. [CrossRef]

57. Espinet, J.M.; Saez, M.; Coenders, G.; Fluiva, M. Effect on prices of the attributes of holiday hotels: A hedonic price approach. Tour. Econ. 2003, 9, 165-177. [CrossRef]

58. Zhang, H.; Zhang, J.; Shaojing, L.; Cheng, S.; Zhang, J. Modeling hotel room price with geographically weighted regression. Int. J. Hosp. Manag. 2011, 30, 1036-1043. [CrossRef]

59. Lennox, J. Impacts of high oil prices on tourism in New Zealand. Tour. Econ. 2012, 18, 781-800. [CrossRef]

60. Qu, H.; Xu, P.; Tan, A. A simultaneous equations model of the hotel room supply and demand in Hong Kong. Int. J. Hosp. Manag. 2002, 21, 455-462. [CrossRef]

61. Enz, C.; Canina, L.; Lomanno, M. Competitive pricing decisions in uncertain times. Cornell Hosp. Q. 2009, 50, 325-341. [CrossRef]

62. Chen, Y.; Fay, S.; Wang, Q. The role of marketing in social media: How online consumer reviews evolve. J. Interact. Mark. 2011, 25, 85-94. [CrossRef]

63. Chen, C.M.; Chang, K.L. Effect of price instability on hotel profitability. Tour. Econ. 2012, 18, 1351-1360. [CrossRef]

64. Mauri, A.G.; Minazzi, R. Web reviews influence on expectations and purchasing intentions of hotel potential customers. Int. J. Hosp. Manag. 2013, 34, 99-107. [CrossRef]

65. Litvin, S.W.; Goldsmith, R.E.; Pan, B. Electronic word-of-mouth in hospitality and tourism management. Tour. Manag. 2008, 29, 458-468. [CrossRef] 
66. Mudambi, S.M.; Schuff, D. What makes a helpful review? A study of customer reviews on Amazon.com. MIS Q. 2010, 34, 185-200. [CrossRef]

67. Vermeulen, I.E.; Seegers, D. Tried and tested: The impact of online hotel reviews on consumer consideration. Tour. Manag. 2009, 30, 123-127. [CrossRef]

68. Pantelidis, I.S. Electronic meal experience: A content analysis of online restaurant comments. Cornell Hosp. Q. 2010, 51, 483-491. [CrossRef]

69. Ryu, K.; Han, H. Influence of the quality of food, service, and physical environment on customer satisfaction and behavioural intention in quick-casual restaurants: Moderating role of perceived price. J. Hosp. Tour. Res. 2010, 34, 310-329. [CrossRef]

70. Zhang, Z.Q.; Ye, Q.; Law, R.; Li, Y.J. The impact of e-word-of-mouth on the online popularity of restaurant: A comparison of consumer reviews and editor reviews. Int. J. Hosp. Manag. 2010, 29, 694-700. [CrossRef]

71. Gössling, S.; Hall, C.M.; Anderson, A.C. The manager's dilemma: A conceptualization of online review manipulation strategies. Available online: http:/ / www.tandfonline.com/doi/full/10.1080/13683500.2015. 1127337 (accessed on 15 September 2018).

72. Hu, N.; Liu, L.; Zhang, J.J. Do online reviews affect product sales? The role of reviewer characteristics and temporal effects. Inf. Technol. Manag. 2008, 9, 201-214. [CrossRef]

73. Porter, M.E. Competitive Strategy; Free Press: New York, NY, USA, 1980.

74. Grönroos, C. Service Management and Marketing: Customer Management in Service Competition; Willey \& Sons: Hoboken, NJ, USA, 2007.

75. Payne, A.; Frow, P. A strategic framework for customer relationship management. J. Mark. 2005, 69, 167-176. [CrossRef]

76. Payne, A.; Holt, S. Diagnosing customer value: Integrating the value process and relationship marketing. Br. J. Manag. 2001, 12, 159-182. [CrossRef]

77. Zeithaml, V.A. Consumer perceptions of price, quality, and value: A means-end model and synthesis of evidence. J. Mark. 1988, 52, 2-22. [CrossRef]

78. Anderson, J.C.; Narus, J.A. Business marketing understand what customer value. Harv. Bus. Rev. 1998, 76, 53-65. [PubMed]

79. Holbrook, M.B. The nature of customer value: An axiology of services in the consumption experience. In Service Quality: New Directions in Theory and Practice; Rust, R.T., Oliver, R.L., Eds.; Sage Publications: Thousand Oaks, CA, USA, 1994; pp. 21-71.

80. Rust, R.T.; Oliver, R.L. Service quality: Insights and managerial implications from the frontier. In Service Quality: New Directions in Theory and Practice; Rust, R.T., Oliver, R.L., Eds.; Sage Publications: Thousand Oaks, CA, USA, 1994; pp. 1-19.

81. Prebensen, N.K.; Woo, E.; Chen, J.S.; Uysal, M. Motivation and involvement as antecedents of the perceived value of the destination experience. J. Travel Res. 2012, 52, 253-264. [CrossRef]

82. Jeong, M. Evaluating value-added lodging web sites from customers' perspectives. Int. J. Hosp. Tour. Adm. 2002, 3, 49-60. [CrossRef]

83. ISTAC. Demanda Turística: Turistas y Pasajeros. 2015. Available online: http://www.gobiernodecanarias. org/istac/temas_estadisticos/sectorservicios/hosteleriayturismo/demanda/ (accessed on 23 April 2017).

84. ICCEX. El Sector del Turismo en Marruecos. 2011. Available online: http://www.think-med.es/wp-content/ uploads / group-documents/5/1357554892-ICEX2011TurismoMarruecos.pdf (accessed on 20 April 2017).

85. Mellinas, J.P.; Martínez María-Dolores, S.M.; Bernal García, J.J. Booking.com: The unexpected scoring system. Tour. Manag. 2015, 49, 72-74. [CrossRef]

86. Yu, G.; Schwartz, Z. Forecasting short time-series tourism demand with artificial intelligence models. J. Travel Res. 2006, 45, 194-203. [CrossRef]

87. Gretzel, U. Intelligent systems in tourism: A social science perspective. Ann. Tour. Res. 2011, 38, 757-779. [CrossRef]

88. Borràs, J.; Moreno, A.; Valls, A. Intelligent tourism recommender systems: A survey. Expert Syst. Appl. 2014, 41, 7370-7389. [CrossRef]

(C) 2018 by the authors. Licensee MDPI, Basel, Switzerland. This article is an open access article distributed under the terms and conditions of the Creative Commons Attribution (CC BY) license (http://creativecommons.org/licenses/by/4.0/). 